\title{
Competitive Strategies Applying in Cultural Museums through Tourism Industry: The Case of Taiwan Hualien
}

\author{
Maw-Cherng $\operatorname{Lin}^{1}$ \\ ${ }^{1}$ Graduate Institute of Hospitality and Tourism Management, Taiwan Hospitality \& Tourism University, Taiwan, \\ ROC \\ Correspondence: Maw-Cherng Lin, 268, Chung-Hsing St., Feng-Shan Village, Shou-Feng Township, Hualien \\ County 94748, Taiwan. Tel: 886-3-865-3906 ext. 7116. E-mail: lin@mail.tht.edu.tw
}

Received: October 23, 2015

Accepted: November 4, 2015

Online Published: December 25, 2015

doi: 10.5539/ibr.v9n1p83

URL: http://dx.doi.org/10.5539/ibr.v9n1p83

\begin{abstract}
In the competition of leisure resources and reduction of governmental budgets over the years, the way in which cultural museums survive and develop is a critical issue. Using the Hualien Hakka Cultural Museum as an example, this study conducted a literature review and analysis, and held local forums, workshops and in-depth interviews using a bottom-up model and an interactive model, in order to collect opinions from industry, government and academia. Through SWOT analysis, TOWS matrix theory and Analytic Network Process (ANP), this study identified the effective Co-opetition Strategy of cultural museums as a reference for the future operation of local Hakka cultural museums.
\end{abstract}

Keywords: local cultural museum, co-opetition strategy, SWOT/TOWS, ANP, tourism industry

\section{Introduction}

Globalization accelerates the flow of global capital, population and goods, with a focus on both "global" and "local" issues. In order to promote Hakka culture, the Taiwanese government established the Hakka Affairs Council in 2001, and launched the "Plan for Hakka Culture Empowerment" to revive Hakka cultural museums. The Hakka Affairs Council approved nearly 80 Hakka museums that were registered, running or in development. These museums showcase the Hakka culture, preserve cultural and historic resources and create job opportunities and economic benefits (Lin, 2015). In the past, in Taiwan, regarding the reuse of idle space, many cultural museums were restricted by original spatial planning, which affected the cultural activities, with problems of space shortage or inappropriate functions. After the opening, some museums were not even in operation. In order to respond to the demand of cultural tourism, Hakka culture and the change of social structure, Hakka cultural policy in Taiwan has shifted from the construction of Hakka cultural museums to the integration of cultural life into the community in order to connect with Hakka cultural facilities and resources in the local area and satisfy visitors' needs.

The tourism industry has been called a "Smokeless Industry". Nowadays, leisure tourism is vitally important worldwide. Leisure activities are popular and different countries actively develop their tourism industries through the use of natural and human resources. According to the report of the World Travel \& Tourism Council (WTTC) in 2014, in 2013, the global output of the tourism industry was about 7.3 trillion USD and accounted for $9.5 \%$ of global GDP; it is estimated that in the future, this figure will increase to 10.8 trillion USD in 2024 (WTTC, 2014) by a Compound Annual Growth Rate of $4.4 \%$. The tourism industry has become one of the Top 2 industries in the world. According to statistics, the tourism industry is the most important source of foreign exchange in many countries. It is critical in the economic performance of all countries (Lin, 2015).

In order to probe into the current situation and prospects of the Hualien Hakka Cultural Museum, this study conducted a literature review and analysis and held three local forums in Hakka communities in northern, central and southern areas using a bottom-up model and an interactive model. Community workshops and in-depth interviews were held in eleven museums to explore the internal and external environments of Hakka cultural museums and collect opinions from industry, government and academia. By using SWOT analysis, TOWS matrix theory and the BCRU (Business model of Culture Relics Museums) decision model (Lin, 2015) of multi-criteria decision-making, this study explores opportunities and threats from the external environment surrounding the Hualien Hakka Cultural Museum, as well as the advantages and disadvantages of the internal 
environment. Based on these results, suggestions for a Co-opetition Strategy for different museums are proposed as reference for the development of local Hakka cultural museums in Hualien.

\section{Literature Review}

In order to enhance culture and make full use of facilities, it is important to encourage public participation in tourist activities. The depth and content of local tourism should be enhanced by culture. Based on a literature review and expert opinions, this study proposed the following dimensions.

\subsection{Cultural Tourism and the Tourism Industry}

In a broad sense, tourism includes cultural tourism, leisure tourism, health tourism, sports tourism, conference tourism, adventurous tourism, business tourism and pilgrimage (Picard, 1996, p. 164). Graburn (1989) explained the content of tourism, and classified it into natural tourism and cultural tourism. The World Tourism Organization (UNWTO) defines cultural tourism as tourism behaviour for a specific cultural motive. It satisfies people's multiple needs and tries to enhance cultural literacy by imparting new knowledge, economy and experience. It includes participation in cultural trips to see performance art, participation in festivals or other cultural activities, visits to historic relics, the study of nature, folk customs or art, and religious tourism (Zeppei \& Hall, 1992). Greg (1996) suggested that cultural tourism means that people leave their homes to absorb new information and experience in cultural sites, in order to satisfy their cultural needs.

Museums, art exhibition halls, traditional tourist sites, historic buildings, historic relics and art festivals gradually become main tourist spots (Weiler \& Hall, 1992). Participation in festivals has become an important part of modern tourism (Picard \& Robinson, 2006). According to Poria, Butler, and Airey (2003), tourists' local experience is the key to cultural tourism and it is associated with local tourism models and tourists' personal backgrounds. Development of cultural tourism has become part of the phenomenon of globalization and many countries treat cultural tourism as a development strategy to enhance local economic growth. How to deal with tourism development and maintain local culture is currently an important issue for the cultural tourism industry. Jafari (1996) indicated that the tourism industry is a kind of social cultural phenomenon, and it is difficult to define its scope. It is associated with different dimensions, although its focus is on economy and culture. Cultural tourism is the most diverse type, with the largest scope and economic benefits among all categories of tourism. Different from mass tourism, which is based on high flow, low cost and provides a package of goods, cultural tourism is based upon low flow, high cost and provides a customized service.

Cultural tourism is tourist activity that interacts with cultural environments, including the landscape, visual performance art and other unique elements of the regional lifestyle, and which values tradition, events and creative cultures. Regarding the enhancement of local tourism by art, Aoyama (2009) suggested that through cooperation between local artists, cultural consumption of tourists, governmental support and subsidies, local sustainable development can be maintained. In brief, cultural tourism includes various kinds of tourism and people can thus learn about the thoughts and lifestyle of different cultures.

One of the key issues concerning the tourism industry is preservation, which includes physical space, the environment or place and a non-material sense of completeness. Through appropriate plans and structural design, balance can be achieved between the tourism industry and the preservation of capital and objects. From the perspective of anthropology, tourism is a cultural activity and it is directly associated with museums, cultural assets and historic relics. All kinds of tourism phenomena directly and significantly influence the countries. The key is to deal with the economy and drive conflict between the tourism industry and cultural value (Throsby, 2001).

The content of tourism should be enhanced by culture. The economic value of culture is developed by tourism development. In recent years, cultural tourism has become a key trend in the tourism industry. It is characterised by a drive to enhance residents' life quality and main assets to obtain internal investment and attract tourists. The phenomenon has not developed naturally but is designed and operated by humans. Tourists visit the historic relics or festivals, since they are attracted by the local human landscape or the unique culture. Based on the above, cultural tourism refers to all kinds of human activities in a country or region through national habit, religious rituals, folk art and traditional art, as well as all cultural activities that are presented to tourists in different places and at different times. Therefore, this study focuses on the particular cultural content constructed by the Hakka ancestors at different times in different areas of Hualien after national integration. They enrich the tourist locations and reinforce local industry.

\subsection{Hakka Culture and Tourism Industry}

'Hakka culture' refers to the Hakka's unique material culture and spiritual culture as well as the Hakka life style. 
Local characteristics refer to the resources to construct or represent local images or spirit. They include nature, ecology, humanity, local specialties and festivals. The central tenet of ethnic tourism is "uniqueness", of which the most attractive part is the unique regional culture. Thus, the creation of a powerful cultural image is the priority of Hakka townships. For instance, Fonglin Township (Hualien County), Beipu Township (Hsinchu County), Xinpu Township (Hsinchu County) and Meinong District (Kaohsiung City) are well-known for their unique Hakka cultural images. Falassi (1987) suggested that festivals are cultural events or social phenomena in people's real lives. Regarding regional tourism development, a unique style is required to attract the tourists, such as races, language, buildings, customs and festivals. Willim (1997) suggested that festivals are thematic activities of public celebration. They create community uniqueness and enhance local residents' identification. Quinn (2009) mentioned that the characteristics of festivals and public celebrations are important, since festivals and activities are important public ceremonies in the long term. They are continuous cultural customs for the public. Therefore, the "cultural tourism" developed in Hakka townships means that there are accessible characteristics and tourism through local resources, human design and Hakka images. Tourism includes not only travelling and sightseeing, but also economic, educational, social and cultural significance. It involves recreational activities and intellectual trips for physical and mental health.

\subsection{Combination of Local Festivals and Marketing}

Cultural museums are mostly based on static operations, which combine local festivals with their plans, and can thus increase their profits. Festivals become global travelling phenomena (Getz, 1991; Prentice \& Andersen, 2003). Festivals are usually associated with events. Allen et al. (2002) suggested that events are the unique rituals, ceremonies, performances and celebrations designed to take place at a specific time. Events include different scales, such as the Olympic Games and expositions of Mega-events, Special Events, Hallmark Events and Community Events. Festivals are usually Hallmark Events and Community Events (Hall, 1989) and are organized by cities, districts or local governments.

Festivals emphasize the culture of the local community. Getz (1997) suggested that festivals are public themed celebrations which demonstrate the historical meanings of community and important cultural practice of society. Uysal and Gitelson (1994) suggested that festivals are the plans to transform the traditional events into important measures to enhance tourism and attract potential tourists.

Generally speaking, festivals refer to celebrations and to the recollection and presentation of culture in a certain region, district or country. They are global cultural phenomena and are valued in academic study, policy establishment, tourism, art and community development (Robinson, Picard, \& Long, 2004). Therefore, in the world, many countries and areas develop tourism, create an urban image and enhance the local economy through local festivals (Hall, 1992; Xie, 2004). Regarding local development, culture can create "Economies of agglomeration". Local buildings are reused and communities are restored. Enhancement of "local life quality" is certain (Heilbrun \& Gray, 2001).

Currently, many areas apply the marketing theory of cultural tourism to regional development and there are several successful cases. However, since the regions have different resources, the cases cannot be applied to all situations. Operation and planning of the itinerary of cultural tourism can be based on the cooperation between the community and the travel industry, with the characteristics of local resources. It can combine tourism with local industrial activities. Uysal and Hagan (1993) suggested that short-term festivals based upon local human resources and cultural assets can reinforce the local image and attract tourists. Moreover, consumption of festivals can lead to the development of the local economy. Therefore, the future individual and collective operation of Hualien Hakka museums can be based on regional festivals.

\subsection{Operation of Strategic Management}

Natural selection is the cruel principle by which creatures survive in nature. Business organizations are no exception. Therefore, how to survive and not be eliminated by the environment is the key concern of enterprises. With national financial difficulty, operation of future Hakka cultural museums will also be difficult; thus, in order to strengthen the use of Hakka cultural museums, we should develop precise and complete plans. Strategic management is one measure that would be appropriate. According to the literature on strategic planning, we can develop effective strategic analytical tools such as SWOT analysis and the TOWS matrix.

(a) SWOT analysis helps us to recognize and confirm the appropriate operational strategies, internal strengths, weaknesses and environmental opportunities and threats (Proctor, 1997) for organizations. External opportunities and threats mean that organizations benefit from or are harmed by society, the economy, the population, culture, politics, the environment and law. Internal strengths and weakness mean the execution of activities which can be controlled in organizations, such as their software and hardware. SWOT analysis was originally applied to the 
formation of corporate strategy (Weihrich, 1982) and then more widely applied to the formation of overall strategy of enterprises (Weihrich, 1993; Proctor, 1997, 2000), industrial strategy analysis (Lin, 2015) or strategic planning for the tourism industry (Ramos, Salazar, \& Gomes, 2000).

(b) TOWS matrix theory and Analytic Network Process (ANP): The TOWS matrix was proposed by Weihrich in 1982 and it aims to validate and construct (1) SO strategies; (2) WO strategies; (3) ST strategies; and (4) WT strategies using the results of SWOT analysis, matching tools to the TOWS matrix of Threats-Opportunities-Weaknesses-Strengths and logic reduction and connection, as shown in Figure 1.

\begin{tabular}{|c|c|c|}
\hline External & \begin{tabular}{cc}
\multicolumn{2}{c}{ Internal Strengths $(\mathrm{S})$} \\
1. \\
2. & (Advantages) \\
& (Advantages)
\end{tabular} & $\begin{array}{c}\text { Internal Weaknesses }(\mathrm{W}) \\
\text { 1. } \\
\text { 2. }\end{array}$ \\
\hline $\begin{array}{l}\text { External Opportunities } \\
\qquad \begin{array}{l}(\mathrm{O}) \\
\text { 1. (Opportunities) } \\
\text { 2. (Opportunities) }\end{array}\end{array}$ & $\begin{array}{l}\text { SO strategies } \\
\text { To obtain opportunities by strengths } \\
\text { (Max.-Max.) }\end{array}$ & $\begin{array}{c}\text { WO strategies } \\
\text { To overcome weakness by obtaining } \\
\text { opportunities } \\
\text { (Min.-Max.) }\end{array}$ \\
\hline External Threats $(\mathrm{T})$ & ST strategy & WT strategies \\
\hline $\begin{array}{l}\text { 1. (Threats) } \\
\text { 2. (Threats) }\end{array}$ & $\begin{array}{l}\text { To avoid threats by strengths } \\
\text { (Max.-Min.) }\end{array}$ & $\begin{array}{l}\text { To avoid weakness and threats } \\
\text { (Min.-Min.) }\end{array}$ \\
\hline
\end{tabular}

Figure 1. Principles of the TOWS matrix

Source: David, 1997; Lin, 2015.

According to recent studies (Frost, 2003; Kearns, 2006; Akli Achabou et al., 2009; Schroeder et al., 2010; Sanchis-Palacio et al., 2011; Atta-Ur-Rahman et al., 2012; Jeroen et al., 2012; Rodrigo et al., 2015; Belmondo et al., 2015), SWOT analysis is often combined with a TOWS matrix to develop the effective strategic planning needed by cases. However, because of the dependence of assessment criteria, this study deals with the planning of a Co-opetition Strategy of local Hakka cultural museums in Hualien using a BCRU decision-making model constructed via a SWOT-TOWS matrix theory and ANP.

\section{Empirical Analysis of Cultural Museum}

\subsection{Background of Hualien Hakka Cultural Museum}

According to the Hakka Basic Act in Taiwan, townships where at least one third of the population is Hakka are the key development areas for Hakka culture. Inheritance and communication of the Hakka language, culture and cultural industry are enhanced. In Hualien County, the Hakka development areas are Hualien City, Jian Township, Shoufeng Township, Fonglin Township, Guangfu Township, Rueisuei Township, Yuli Township and Fuli Township, as shown in Figure 2. Hakka cultural communities in the northern, central and southern areas are shown in Figure 3.

Hakka cultural museums in Hualien County can be classified into general cultural museums, historic cultural museums, natural science cultural museums, industrial cultural museums, performance cultural museums and artistic cultural museums. In Hualien County, there are currently one county, six township, two community and two private Hakka cultural museums, as shown in Figure 4.

\subsection{Assessment of Co-Opetition Strategy of Hualien Hakka Cultural Museum}

\subsubsection{Decision-making Evaluation Procedure}

Operational strategies of Hualien Hakka Cultural Museum are broad and complicated and they should be treated with tolerant and flexible measures. ANP is based on complicated decision-making of dependence and feedback among the factors associated with this study. It can obtain most experts' opinions. Through consistency testing, it shows the coherence and logic of experts' comparisons of criteria. The assessment framework is shown in Table 1. 


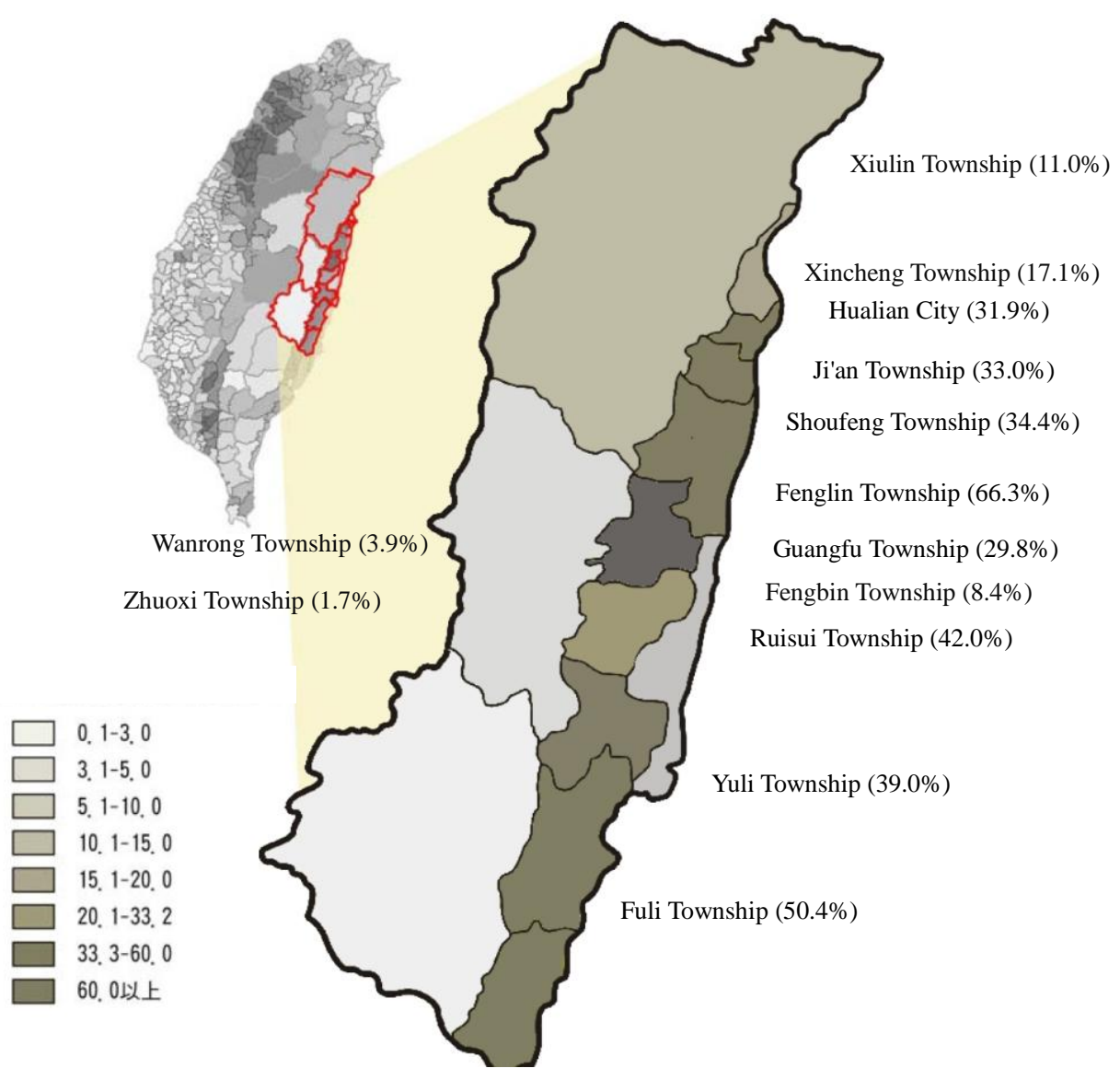

Figure 2. Locations and percentages of Hakka population in Hualien County

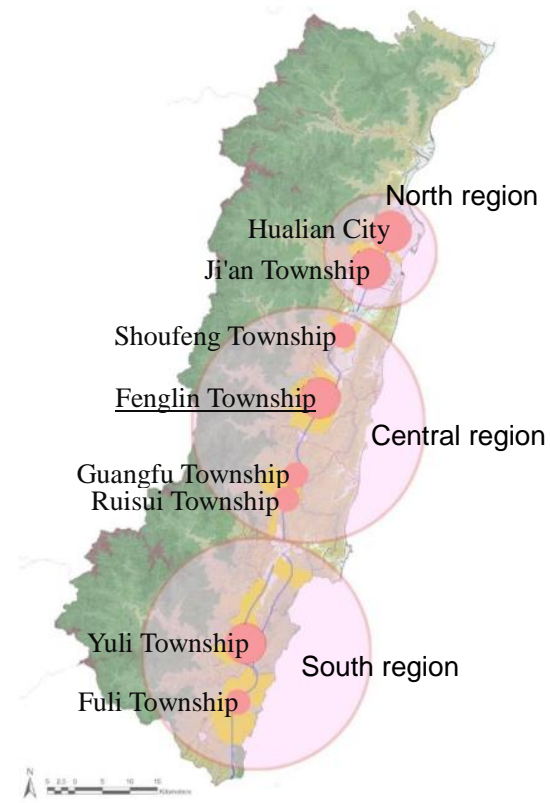

Figure 3. Hakka culture communities of northern, central and southern areas of Hualien County 


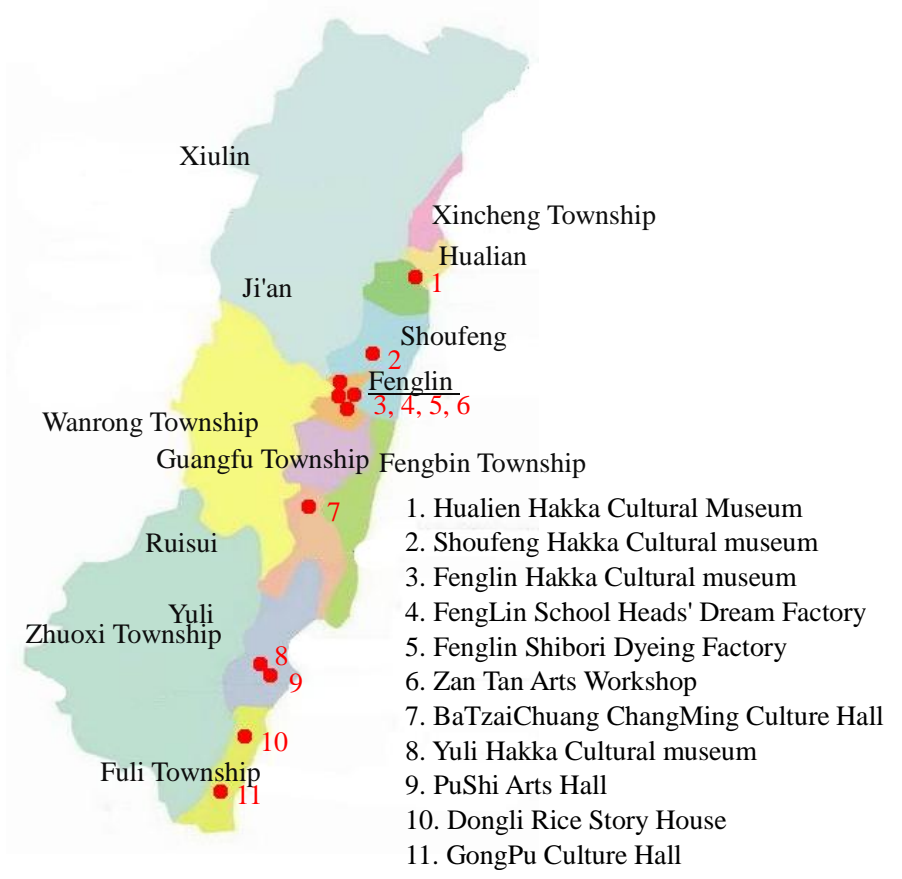

Figure 4. Distribution of Hakka cultural museums in Hualien

Table 1. General evaluation of operational strategies of cultural museums

\begin{tabular}{cccccccc}
\hline Feasible & $C_{1}$ & $C_{2}$ & $C_{3}$ & $\ldots$ & $C_{j}$ & $\ldots$ & $C_{m}$ \\
\cline { 2 - 8 } strategy & $w_{1}$ & $w_{2}$ & $w_{3}$ & $\ldots$ & $w_{j}$ & $\ldots$ & $w_{m}$ \\
$A_{1}$ & $r_{11}$ & $r_{12}$ & $r_{13}$ & $\ldots$ & $r_{1 j}$ & $\ldots$ & $r_{1 m}$ \\
$A_{2}$ & $r_{21}$ & $r_{22}$ & $r_{23}$ & $\ldots$ & $r_{2 j}$ & $\ldots$ & $r_{2 m}$ \\
$:$ & $:$ & $:$ & $:$ & $\ldots$ & $:$ & $\ldots$ & $:$ \\
$A_{e}$ & $r_{e 1}$ & $r_{e 2}$ & $r_{e 3}$ & $\ldots$ & $r_{e j}$ & $\ldots$ & $r_{e m}$ \\
$:$ & $:$ & $:$ & $:$ & $\ldots$ & $:$ & $\ldots$ & $:$ \\
$A_{n_{k}}$ & $r_{n_{k} 1}$ & $r_{n_{k} 2}$ & $r_{n_{k} 3}$ & $\cdots$ & $r_{n_{k} j}$ & $\ldots$ & $r_{n_{k} m}$ \\
\hline
\end{tabular}

It is assumed that in Hualien Hakka Cultural Museum, there is $A_{n_{k}}$ feasible strategy. The weight of assessment criterion $C_{j}$ determined by the judge is $w_{j}(j=1,2, \ldots, m)$ and the rating of the feasible strategy of assessment criterion $C_{j}$ is $r_{e j}$ Hence, Multiple Criteria Decision Making (MCDM) is used to investigate and assess the feasible strategy of the cultural museum. The decision-making evaluation process is shown as follows.

\section{Step 1: Composition of decision group}

According to the field and complexity of the decision-making issue, this study formed a decision group with five government officials, five scholars, five managers, five local residents, and five tourists.

Step 2: Construction of problem structure

According to the literature review, the decision group interview, and group brainstorming, this study determined the system factors of decision-making. The assessment dimensions were generalized as government policy $\left(D_{1}\right)$, location of cultural museum $\left(D_{2}\right)$, facility planning and construction $\left(D_{3}\right)$ and service planning and application $\left(D_{4}\right)$, as shown in Figure 5.

Assessment dimensions of government policy $\left(D_{1}\right)$ include the completeness of regulations $\left(C_{1}\right)$, support of funds $\left(C_{2}\right)$, completeness of public facilities $\left(C_{3}\right)$, and the convenience of transportation $\left(C_{4}\right)$; assessment dimensions of the location conditions of the cultural museum $\left(D_{2}\right)$ include the location of the cultural museum $\left(C_{5}\right)$, characteristics of the cultural museum $\left(C_{6}\right)$, local residents' participation and passion $\left(C_{7}\right)$, ticket prices $\left(C_{8}\right)$, tourist spots in the neighbourhood and their attractiveness $\left(C_{9}\right)$ and thematic spots $\left(C_{10}\right)$; the assessment dimension of facility planning and construction $\left(D_{3}\right)$ includes preservation of historic relics or buildings $\left(C_{11}\right)$, 
cleanness and comfort $\left(C_{12}\right)$, leisure facilities $\left(C_{13}\right)$, use or visit route $\left(C_{14}\right)$; the assessment dimension of service planning and application $\left(D_{4}\right)$ includes satisfaction with the guide and the explanation of facilities $\left(C_{15}\right)$, completeness of historic and cultural information $\left(C_{16}\right)$, attraction of traveling literature $\left(C_{17}\right)$, the accessibility and richness of experiential activities $\left(C_{18}\right)$, and the characteristics and prices of souvenirs $\left(C_{19}\right)$, as shown in Figure 6.

Step 3: Questionnaire design and survey

The experts in the decision-making group judged the relative importance of factors according to the assessment of the hierarchical structure, based on the previous factor.

Step 4: Integration of expert preference

It is assumed that there are $R$ experts in the decision-making group The experts judged the relative importance of the factors of different levels based on the constructed hierarchical structure. For pairwise comparison of $n$ factor, the experts obtained one pairwise comparison matrix $A^{h}(h=1,2, \ldots, R)$ :

$$
\left.A^{h}=\left(a_{i i^{\prime}}^{h}\right), i i^{\prime}=1,2, \ldots, n\right)
$$

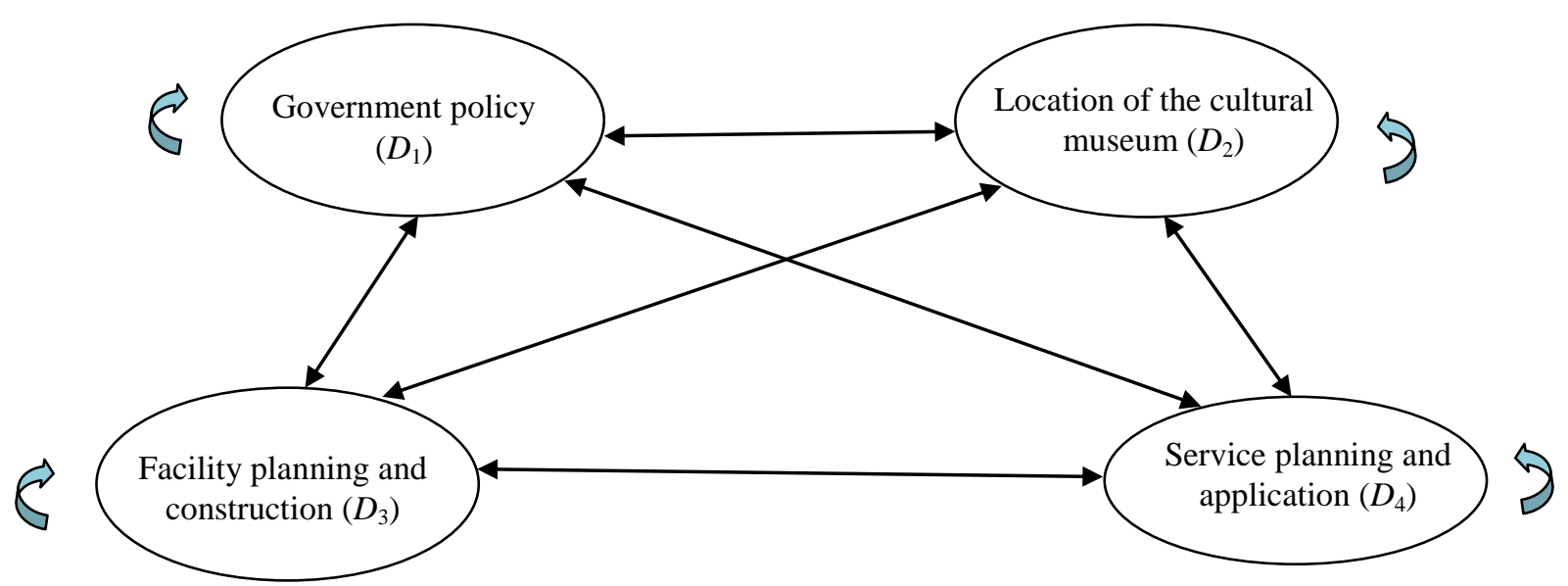

Figure 5. ANP decision-making model of operational strategy assessment of Hualien Hakka Cultural Museum Note. The solid lines mean outer dependence; bold curved arrows denote inner dependence.

Source: Compiled by this study.

The experts might have different cognitions toward the problems and the values of pairwise comparison also differ: thus, their preferences are summarized. Among the commonly used geometric mean and majority rule, this study adopts the geometric mean. $R$ experts meet consistent pairwise comparison value, integrated by the geometric mean. Matrix $A$ of the integrated pairwise comparison matrix is below

$$
\begin{aligned}
A & =\left(a_{i i^{\prime}}\right) \\
a_{i i^{\prime}} & =\left(\prod_{h=1}^{R} a_{i i^{\prime}}^{h}\right)^{1 / h}, i i^{\prime}=1,2, \ldots, n
\end{aligned}
$$

Step 5: Construction of weights of factors of pairwise comparison matrix

Using the relative importance of $m$ assessment criteria as an example, this paper compares the relative importance of assessment criterion $C_{j}$ and assessment criterion $C_{j}$ and judgment of the judge $h$ is shown as $w_{i j}^{h c}$ and $w_{j i}^{h c}$,

$$
w_{i j}^{h c}=1 / w_{j i}^{h c}, \forall h
$$

According to relative importance, $w_{i j}^{\text {hc }}$ refers to 1-9.

Based on the previous comparison, this paper constructs an $m \times m$ pairwise comparison matrix $D_{c}^{h}$ and the elements are shown as follows: 

(a) $d_{i j}^{h c}=1, i=j, \forall h$
(b) $d_{i j}^{h c}=w_{i j}^{h c}, i \neq j, \forall h$
(c) $d_{j i}^{h c}=1 / d_{i j}^{h c}, \forall h$

Step 6: Consistency test

Finally, the maximum eigenvalue $\lambda_{\max }$ of matrix $D_{c}^{h}$ and the corresponding eigenvector $W_{h}$ can be obtained:

$$
D_{c}^{h} W_{h}=\lambda_{\max } W_{h}
$$

$W_{h}=\left(w_{1}^{h}, w_{2}^{h}, \ldots, w_{m}^{h}\right)^{T}$ and it is the weight of $m$ objectives obtained by the judgment of judge $h$. Since matrix $D_{c}^{h}$ is a positive reciprocal matrix, $D_{c}^{h}$ only has one maximum eigenvalue $\lambda_{\max }$ and the remaining eigenvalues are 0 . Theoretically, $\lambda_{\max }$ should be equal to $m$. Since human judgment might be inconsistent, $\lambda_{\max }$ is higher than $m$. Thus, using the Consistency Index $(C I)$, this study attempts to find out whether the decision-makers' judgment is consistent.

$$
C I=\left(\lambda_{\max }-m\right) /(m-1)
$$

When $C I \leq 0.1$, the judges' subjective judgment is consistent (Saaty, 1980). $W_{h}$ is objective weight vector upon subjective judgment of the judge $h$.

Step 7: Calculation of hyper matrix

There is dependence among factors in the problems. ANP aims to cultivate the relative weights of factors by using a hyper matrix. A hyper matrix consists of many sub-matrixes. A sub-matrix is a pairwise comparison matrix obtained by Eq. (1). When there is no relationship among the factors, pairwise comparison of the sub-matrix is 0 . Since there is external dependence between the assessment dimension and the assessment criterion in this study, sub-matrix $F$ means a pairwise comparison matrix of assessment criterion in the assessment dimension. Sub-matrix $G$ means a pairwise comparison matrix of the assessment dimension of the assessment criterion. When there is internal dependence among assessment criteria, the pairwise comparison sub-matrix is shown by $H$. When there is no dependence among the assessment dimensions, it is shown by sub-matrix 0 and unweighted hyper matrix $W^{\prime}$ consists of the previous sub-matrix.

$$
W^{\prime}=\left[\begin{array}{ll}
0 & G \\
F & H
\end{array}\right] \quad \begin{aligned}
& \text { Assessment dimension } \\
& \text { Assessment criterion }
\end{aligned}
$$

Step 8: Relative weight acquisition of feasible strategy

With assessment criteria, this paper compares the relative importance of feasible strategies, constructs a pairwise comparison matrix, and integrates the preference to acquire the maximum eigenvalue and corresponding eigen vector. Thus, the relative weights of feasible strategies are obtained.

Step 9: Decision making of the optimal strategy

Decision making of the optimal strategy can be based on the Desirability Index (Desirability Index; DI). The Desirability Index of feasible strategy $A_{i}$ is shown by $D I_{i}(i=1,2, \cdots, n)$,

$$
D I_{i}=\sum_{j=1}^{m} S_{i j}=\sum_{j=1}^{m} R_{j} W_{i j}, \forall i
$$

where, $S_{i j}$ : Weight of $i$ feasible strategy $i$ of assessment criterion $j$.

$R_{j}$ : Relative weight of assessment criterion $j$.

$W_{i j}$ : Relative weight of feasible strategy $i$ of assessment criterion $j$.

Thus, the feasible strategy with the highest Desirability Index is the optimal strategy of the community, shown by $A^{*}$.

$$
A^{*}=\left\{A_{i} \mid D I_{i}=\underset{k=1,2, \cdots, n}{\max } \underset{i m u m}{\operatorname{ing}}\left(D I_{k}\right)\right\}
$$




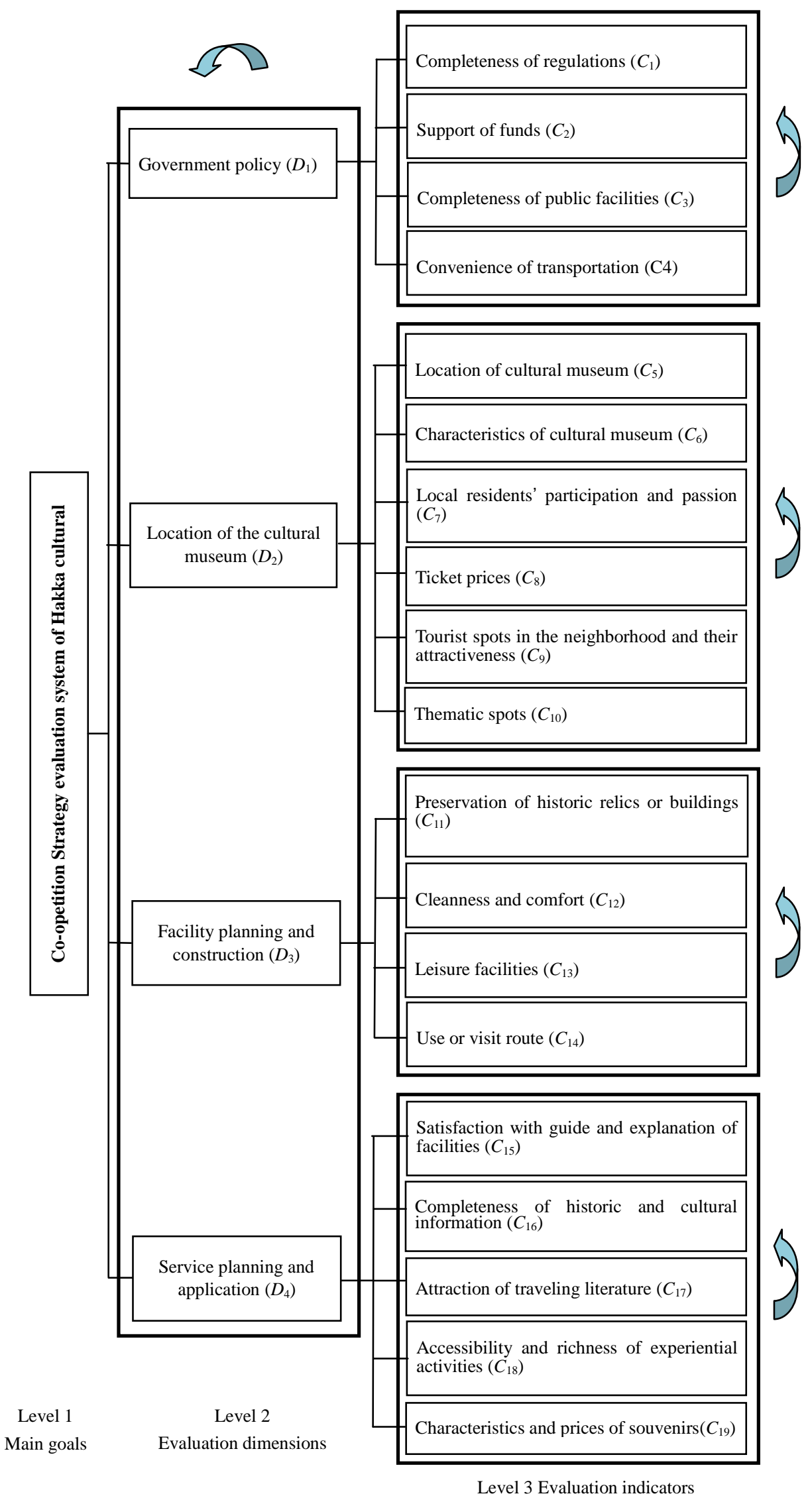

Figure 6. Co-opetition strategy evaluation system of Hualien Hakka Cultural Museum Note. The solid lines mean outer dependence; bold arrow of curve denotes inner dependence. 


\subsubsection{Questionnaire Survey and Result}

According to Step 3, based on characteristics, this study classified questionnaire subjects as follows: government officials, experts and scholars, cultural museum managers, local community residents, and tourists, with a total of 25 subjects, as shown in Table 2. The questionnaire contents were explained to the subjects.

Table 2. Number of valid samples for the expert questionnaire in this study

\begin{tabular}{cc}
\hline Field of experts & Number of valid samples \\
\hline Government officials & 5 \\
Scholars and experts & 5 \\
Cultural museum managers & 5 \\
Local residents & 5 \\
Visitors & 5 \\
Total & 25 \\
\hline
\end{tabular}

After retrieving the expert questionnaire, Eqs. (1) (10) are used to obtain the results by Super Decisions 2.2.3 and the calculation includes (1) construction of a pairwise comparison matrix; (2) calculation of the eigen vector and consistency test; (3) calculation of the super matrix; (4) integration of expert preference; (5) integration of weights of factors. Thus, we obtain the relative weights of criteria of Hakka cultural museums in Hualien County.

a) Weight calculation result of assessment dimensions and discussion

This paper evaluates the Hakka cultural museums of Hualien County in four dimensions: government policy, location condition of cultural museum, facility planning and construction, and service planning and application. The weights of the assessment dimensions are shown in Table 3:

Table 3. Decision-making group weights of assessment dimensions of Hakka cultural museum

\begin{tabular}{ccccccc}
\hline Dimensions & $\begin{array}{c}\text { Government } \\
\text { officials }\end{array}$ & $\begin{array}{c}\text { Scholars and } \\
\text { experts }\end{array}$ & $\begin{array}{c}\text { Cultural } \\
\text { museum } \\
\text { Manager }\end{array}$ & $\begin{array}{c}\text { Local } \\
\text { residents }\end{array}$ & $\begin{array}{c}\text { Visitors } \\
\text { geometric mean }\end{array}$ \\
\hline Government policy $\left(D_{1}\right)$ & 0.2694 & 0.3446 & 0.2362 & 0.1170 & 0.0604 & 0.2055 \\
Location of the cultural museum $\left(D_{2}\right)$ & 0.3553 & 0.2647 & 0.2331 & 0.2197 & 0.5151 & 0.3176 \\
Facility planning and construction $\left(D_{3}\right)$ & 0.2166 & 0.1876 & 0.2616 & 0.2636 & 0.2042 & 0.2267 \\
Service planning and application $\left(D_{4}\right)$ & 0.1587 & 0.2031 & 0.2691 & 0.3997 & 0.2203 & 0.2502 \\
\hline
\end{tabular}

Among the weights of different groups, the government officials pay the most attention to government policy and location condition; scholars and experts suggest that cultural museums rely on government policy and the content of cultural museums; cultural museum managers and local residents suggest that enhancement of the content of cultural museums as a priority. Tourists suggest that transportation and sports are the most important.

According to the results of the questionnaire, the ranking of weights of geometric means of dimensions of the cultural museum is shown as follows: (1) location condition of cultural museum (0.3176), (2) service planning and application (0.2502), (3) facility planning and construction (0.2267), (4) government policy (0.2055).

b) Results and discussion of relative weights of assessment criteria

Regarding the operation and performance of Hualien Hakka Cultural Museum, through field interviews and experts' brainstorming, this study constructed nineteen criteria, as shown in Figure 6. The results of steps 3 to 8 of the decision-making procedure are shown in Table 4. 
Table 4. Weights of decision-making group of assessment criteria in Hualien Hakka Cultural Museum

\begin{tabular}{|c|c|c|c|c|c|c|c|}
\hline Assessment criteria & $\begin{array}{l}\text { Government } \\
\text { officials }\end{array}$ & $\begin{array}{l}\text { Scholars } \\
\text { and experts }\end{array}$ & $\begin{array}{l}\text { Cultural } \\
\text { museum } \\
\text { Manager }\end{array}$ & $\begin{array}{l}\text { Local } \\
\text { residents }\end{array}$ & Visitors & Weights & Ranking \\
\hline$C_{1}$ Completeness of regulations & 0.0483 & 0.059 & 0.0396 & 0.03 & 0.0298 & 0.0413 & 16 \\
\hline$C_{2}$ Support of funds & 0.0459 & 0.1011 & 0.0456 & 0.0571 & 0.044 & 0.0587 & 7 \\
\hline$C_{3}$ Completeness of public facilities & 0.0544 & 0.0282 & 0.0451 & 0.0525 & 0.081 & 0.0522 & 10 \\
\hline$C_{4}$ Convenience of transportation & 0.0663 & 0.0415 & 0.032 & 0.0582 & 0.0685 & 0.0533 & 9 \\
\hline$C_{5}$ Location of cultural museum & 0.065 & 0.0389 & 0.0493 & 0.0489 & 0.0794 & 0.0563 & 8 \\
\hline$C_{6}$ Characteristics of cultural museum & 0.11 & 0.0368 & 0.1057 & 0.1261 & 0.0429 & 0.0843 & 1 \\
\hline $\begin{array}{l}C_{7} \text { Local residents' participation and } \\
\text { passion }\end{array}$ & 0.0508 & 0.0419 & 0.0587 & 0.0526 & 0.0532 & 0.0514 & 11 \\
\hline$C_{8}$ Ticket prices & 0.0296 & 0.0232 & 0.0401 & 0.0253 & 0.0181 & 0.0272 & 17 \\
\hline $\begin{array}{l}C_{9} \text { Tourist spots in the neighbourhood and } \\
\text { their attractiveness }\end{array}$ & 0.0419 & 0.0422 & 0.0424 & 0.0322 & 0.0799 & 0.0477 & 13 \\
\hline$C_{10}$ Thematic spots & 0.0484 & 0.0357 & 0.0626 & 0.051 & 0.0559 & 0.0507 & 12 \\
\hline $\begin{array}{l}C_{11} \text { Preservation of historic relics or } \\
\text { buildings }\end{array}$ & 0.0254 & 0.0263 & 0.0232 & 0.0283 & 0.0218 & 0.0250 & 18 \\
\hline$C_{12}$ Cleanliness and comfort & 0.0591 & 0.0746 & 0.0621 & 0.0859 & 0.0497 & 0.0662 & 5 \\
\hline$C_{13}$ Leisure facilities & 0.0755 & 0.0659 & 0.0448 & 0.0577 & 0.0718 & 0.0631 & 6 \\
\hline$C_{14}$ Use or visit route & 0.0676 & 0.0864 & 0.0953 & 0.0736 & 0.0393 & 0.0724 & 3 \\
\hline $\begin{array}{l}C_{15} \text { Satisfaction with guide and } \\
\text { explanation of facilities }\end{array}$ & 0.0631 & 0.0966 & 0.0604 & 0.075 & 0.0504 & 0.0691 & 4 \\
\hline $\begin{array}{l}C_{16} \text { Completeness of historic and cultural } \\
\text { information }\end{array}$ & 0.0646 & 0.089 & 0.0587 & 0.0416 & 0.1451 & 0.0798 & 2 \\
\hline$C_{17}$ Attraction of travelling literature & 0.0151 & 0.0164 & 0.0258 & 0.0107 & 0.0135 & 0.0163 & 19 \\
\hline $\begin{array}{l}C_{18} \text { Accessibility and richness of } \\
\text { experiential activities }\end{array}$ & 0.0349 & 0.0639 & 0.0351 & 0.0498 & 0.0339 & 0.0435 & 14 \\
\hline$C_{19}$ Characteristics and prices of souvenirs & 0.0346 & 0.0328 & 0.074 & 0.0439 & 0.0222 & 0.0415 & 15 \\
\hline
\end{tabular}

Based on the results of the questionnaire, the weights and ranking of assessment criteria in Table 4 are shown as follows:

(1) $C_{6}$ Characteristics of cultural museum (0.0843)

(2) $C_{16}$ Completeness of historic and cultural information (0.0798)

(3) $C_{14}$ Use or visit route $(0.0724)$

(4) $C_{15}$ Satisfaction with guide and explanation of facilities (0.0691)

(5) $C_{12}$ Cleanliness and comfort (0.0662)

(6) $C_{13}$ Leisure facilities $(0.0631)$

(7) $C_{2}$ Support of funds (0.0587)

(8) $C_{5}$ Location of cultural museum (0.0563)

(9) $C_{4}$ Convenience of transportation (0.0533)

(10) $C_{3}$ Completeness of public facilities (0.0522)

(11) $C_{7}$ Local residents' participation and passion (0.0514)

(12) $C_{10}$ Thematic spots $(0.0507)$

(13) $C_{9}$ Tourist spots in the neighbourhood and their attractiveness $(0.0477)$

(14) $C_{18}$ Accessibility and richness of experiential activities (0.0435)

(15) $C_{19}$ Characteristics and prices of souvenirs (0.0415)

(16) $C_{1}$ Completeness of regulations (0.0413)

(17) $C_{8}$ Ticket prices $(0.0272)$ 
(18) $C_{11}$ Preservation of historic relics or buildings (0.025)

(19) $C_{19}$ Attraction of travelling literature (0.0163)

c) Decision making of the optimal development strategy and discussion of results

Cultural museums' development strategies can be restricted by funds and manpower, and might not be practiced at the same time. Thus, it is important to distinguish the importance and urgency of the strategies, in order to adjust the operational guidelines of the museums. This section focuses on Co-opetition Strategies upon TOWS, which are scored by experts and scholars in related fields. By using Simple Additive Weight Method, SAW, as shown in Step 9, the advantages and disadvantages of the cultural museum's development strategies are analyzed, as shown in Table 5. According to the ranking, the strategies are used as reference for the following operation.

Table 5. The optimal TOWS strategy matrix of Hualien Hakka cultural museum

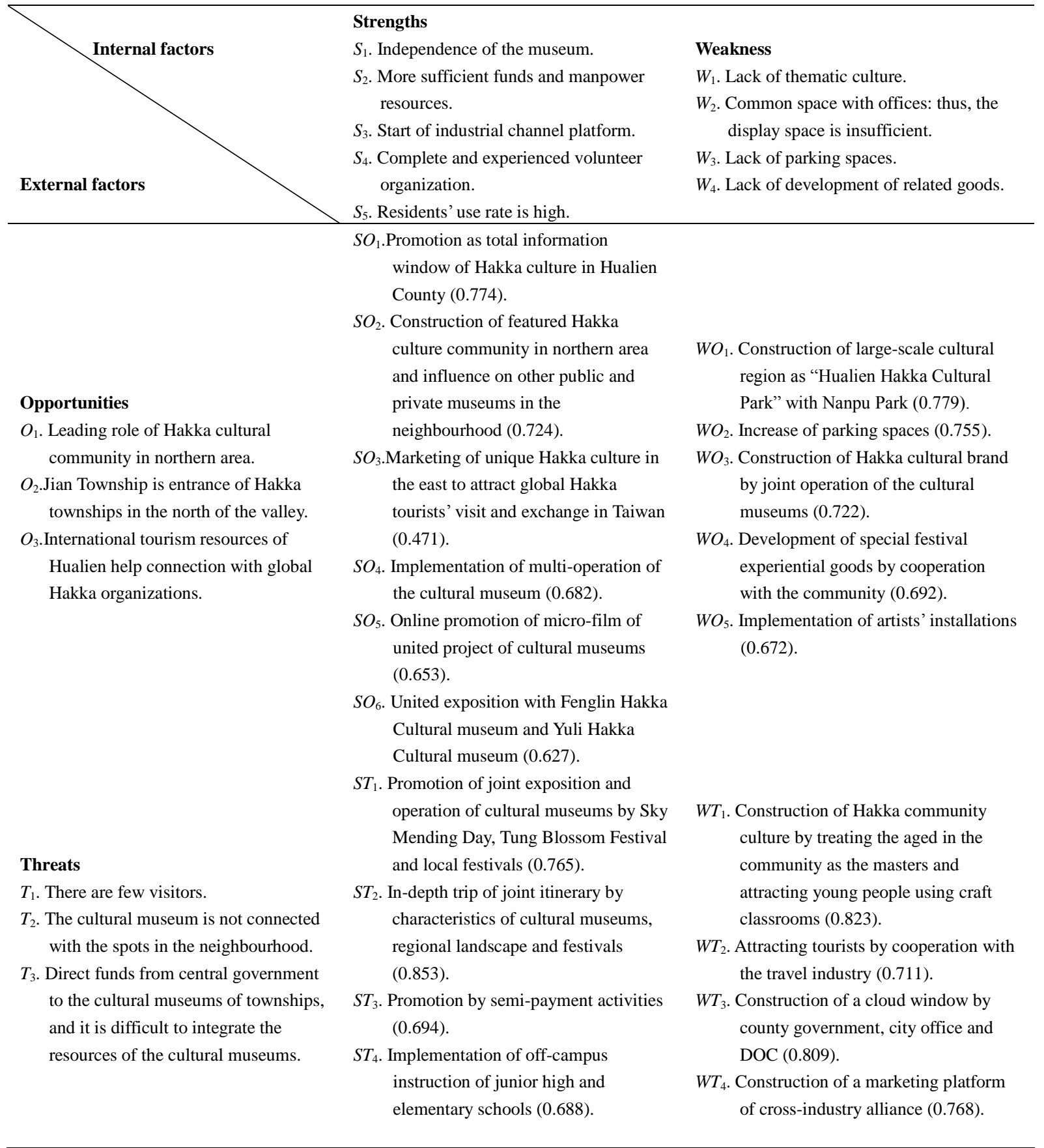


With regard to the SO strategies of the Hualien Hakka Cultural Museum, the priority is $S O_{1}$ "promotion as total information window of Hakka culture in Hualien County" (0.774), followed by $\mathrm{SO}_{2}$ "construction of featured Hakka culture community in northern area and influence on other public and private museums in the neighbourhood" (0.724), $\mathrm{SO}_{4}$ "implementation of multi-operation of the cultural museum" (0.682), $\mathrm{SO}_{5}$ "online promotion of micro-film of united project of cultural museums" (0.635), $S O_{6}$ "united exposition with Fenglin Hakka Cultural museum and Yuli Hakka Cultural museum" (0.627) and $\mathrm{SO}_{3}$ "marketing of unique Hakka culture in the east to attract global Hakka tourists' visit and exchange in Taiwan" (0.471).

As regards WO strategies, the priority is $W O_{1}$, "construction of large-scale cultural region with Nanpu Park [Hualien Hakka Cultural Park]" (0.779), followed by $\mathrm{WO}_{2}$ "increase of parking spaces" (0.755), $\mathrm{WO}_{3}$ "construction of Hakka culture brand by joint operation of the cultural museums" $(0.722), \mathrm{WO}_{4}$ "development of special festival experiential goods by cooperation with community" (0.692) and $\mathrm{WO}_{5}$ "implementation of artists' installations" (0.672).

As to ST strategies, the priority is $S T_{2}$ "in-depth trip of joint itinerary by characteristics of cultural museums, regional landscape and festivals" (0.853) followed by $S T_{1}$ "promotion of joint exposition and operation of cultural museums by Sky Mending Day, Tung Blossom Festival and local festivals" (0.765), $S T_{3}$ "promotion by semi-payment activities" (0.694) and $S T_{4}$ "implementation of off-campus instruction of junior high and elementary schools" $(0.688)$.

As to WT strategies, the priority is $W T_{1}$ "construction of Hakka community culture by treating the aged in the community as the masters and attracting young people using craft classrooms" $(0.823)$ followed by $W T_{3}$ "construction of cloud window by county government, city office and DOC" $(0.809), W T_{4}$ "construction of marketing platform of cross-industry alliance" $(0.768)$ and $W T_{2}$ "attraction of tourists by cooperation with travel industry" (0.711).

Although the demands of industry, government and academia may differ, the goals should be the same. The industry focuses on profits, local governments aim to provide public service and academia and research units should promote research findings. They all intend to provide good service for the public. The driver of the large-scale leisure and tourism industry upon local cultural museums and festivals is local government, which should have the belief to promote local features. In order to accomplish this mission, they must have dedicated teams and the participation of industry and academia, as shown in Figure 7. The activities can be measured via quantitative economic benefits or non-quantitative benefits to create profits for local governments.

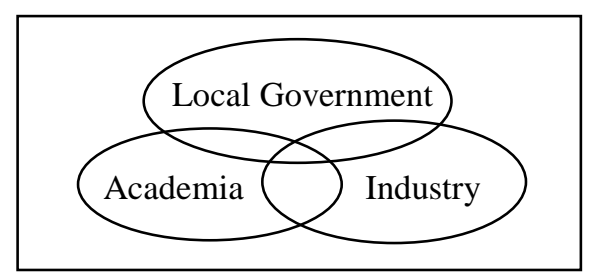

Figure 7. Cooperation among industry, government and academia of local industry

\section{Conclusion}

Through a literature review, investigation of cultural museums, local forums, visits to cultural museums and community workshops, this study has generalized the key factors of the internal strengths and weaknesses of Hualien Hakka Cultural Museum as manpower, administration, organizational management, operational belief, financial structure, positioning of cultural museums, facilities of cultural museums and marketing. The key external opportunities and threats are transportation, the location of the cultural museum, subsidy, tourists, laws and community cooperation.

The SWOT analysis identified the internal strengths and weaknesses in the operation of cultural museums and external opportunities and threats. Finally, the TOWS matrix and ANP revealed the content of the Co-opetition Strategy for operation of cultural museums: (1) SO strategies to obtain external opportunities using the strengths of cultural museums, the priority is $S O_{1}$ "promotion as total information window of Hakka culture in Hualien County" (0.774); (2) WO strategies to overcome internal weaknesses using the external opportunities of cultural museums, the priority is $W_{1}$, "construction of large-scale cultural region with Nanpu Park (Hualien Hakka Cultural Park)" (0.779); (3) ST strategies to avoid external threats using the internal strengths of cultural 
museums, the priority is $S T_{2}$ "in-depth trip of joint itinerary by characteristics of cultural museums, regional landscape and festivals" (0.853); (4) WT strategies to avoid external threats by reducing the internal weaknesses of cultural museums, the priority is $W T_{1}$ "construction of Hakka community culture by treating the aged in the community as the masters and attracting young people using craft classrooms" $(0.823)$.

The findings can serve as a reference for future operation and development of the Hualien Hakka Cultural Museum.

\section{Acknowledgments}

The work described in this article was substantially supported by a grant from the Research Hakkanese culture relics museums of the Hualien County Government, Taiwan [Project No. HAKKA10106]. Next, the author thank Sung-Ken Kao and Yung-Ching Wu for research assistance. Finally, the author would like to express gratitude for the detailed attention and valuable feedback from the two reviewers, and the suggestions and encouragement from the editorial team during the review period.

\section{References}

Allen, J., O’ Toole, W., McDonnell, I., \& Harris, R. (2002). Festival and special events management (2nd ed.). Milton: John Wiley \& Sons Australia.

Akli Achabou, M., \& Selma, T. (2009). The institutional environment in the strategic decision of the emerging companies: The case of the Algerian sugar industry. Journal of Multi-Criteria Decision Analysis, 16(5-6), 139-148. http://dx.doi.org/10.1002/mcda.449

Aoyama, Y. (2009). Artists, Tourists, and the State: Cultural Tourism and the Flamenco Industry in Andalusia, Spain. International Journal of Urban and Regional, 33(1), 80-104. http://dx.doi.org/10.1111/j.1468-2427.2009.00846.x

Atta-Ur-Rahman, Amir, N. K., \& Zulfiqar, A. (2012). Evaluation of the Chashma Right Bank irrigation project and strategy formulation using the SWOT approach. Irrigation and Drainage, 61(4), 464-476. http://dx.doi.org/10.1002/ird.682

Belmondo, Cécile, \& Caroline, S. R. (2015). Negotiating language, meaning and intention: Strategy infrastructure as the outcome of using a strategy tool through transforming strategy objects. British Journal of Management, 26(S1), S90-S104. http://dx.doi.org/10.1111/1467-8551.12070

David, F. R. (1997). Concept of Strategic Management (7th ed). Englewood Cliffs, N. J.: Prentice-Hall.

Falassi, A. (1987). Time out of time, Essays on Festival. U.S.A. University of New Mexico Press.

Frost, \& Frederick, A. (2003). The use of strategic tools by small and medium-sized enterprises: an Australasian study. Strategic Change, 12(1), 49-62. http://dx.doi.org/10.1002/jsc.607

Getz, D. (1991). Festivals, Special events and tourism. New York: Van Nostrand Reinhold.

Getz, D. (1997). Event Management and Event Tourism. New York: Cognizant Communication Corp.

Greg, R. (1996). Production and Consumption of European Cultural Tourism. Annals of Tourism Research, 23(2), 261-283. http://dx.doi.org/10.1016/0160-7383(95)00063-1

Hall, C. M. (1992). Hallmark tourist events: Impact, management and planning. London: Belhaven Press.

Heilbrun, J., \& Gray, C. M. (2001). The Economics of Art and Culture (2nd ed). UK: Cambridge University Press. http://dx.doi.org/10.1017/CBO9780511754135

Jafari, J. (1996). Tourism and culture: An inquiry into paradoxes. Proceedings of round table debate 011 culture, tourism. Development: Crucial Issues for the Celltury, 43-47. UNESCO: Paris.

Van, W. J. D. H., Scholten, G. R. M., \& Van, W. K. P. (2012). Strategic analysis for health care organizations: the suitability of the SWOT-analysis. The International Journal of Health Planning and Management, 27(1), 34-49. http://dx.doi.org/10.1002/hpm.1032

Kearns, K. P. (2006). From comparative advantage to damage control: Clarifying strategic issues using swot analysis. Nonprofit Management and Leadership, 3(1), 3-22. http://dx.doi.org/10.1002/nml.4130030103

Lin, M. C. (2015). Co-opetition Strategy Model of Hakkanese Culture Relics Museums. International Journal of Management Sciences, $\quad$ 5(1), 85-101. $\quad$ Retrieved from http://www.rassweb.com/archive-details-vol-5-issue-1-ijms/

MacCrimmon, K. R. (1968). Decision-making among multiple-attribute alternatives: A survey and 
consolidated approach, RAND Memorandum, RM-4823-ARPA.

Picard, M. (1996). Bali: Cultural Tourism and Touristic Culture. Singapore: Archipelago Press.

Picard, D., \& Robinson, M. (2006). Festivals, tourism and social change. Clevedon: Channel View.

Poria, Y., Butler, R., \& Airey, D. (2003). The core of heritage tourism. Annals of Tourism Research, 30(1), 238-254. http://dx.doi.org/10.1016/S0160-7383(02)00064-6

Prentice, R., \& Andersen, V. (2003). Festival as Creative Destination. Annals of Tourism Research, 30(1), 7-30. http://dx.doi.org/10.1016/S0160-7383(02)00034-8

Proctor, T. (1997). Establishing a strategic direction: A review. Management Decision, 35(2), 143-154. http://dx.doi.org/10.1108/00251749710160304

Proctor, T. (2000). Management tools strategic marking management for health management: cross impact matrix and TOWS. Journal of Management in Medicine, 14(1), 47-56. http://dx.doi.org/10.1108/02689230010340552

Quinn, B. (2009). Festivals, events and tourism. In: T.J amal, \& M. Robinson (Eds.), The sage handbook of tourism studies. http://dx.doi.org/10.4135/9780857021076.n27

Ramos, P., Salazar, A., \& Gomes, J. (2000). Trends in Portuguese tourism: A content analysis of association and trade representative perspectives. International Journal of Contemporary Hospitality Management, 12(7), 409-419. http://dx.doi.org/10.1108/09596110010347266

Robinson, M., Picard, D., \& Long, P. (2004). Festival tourism: Producing, translating, and consuming expressions of culture(s). Introduction. Event Management, 8(4), 187-189. http://dx.doi.org/10.3727/1525995031436836

Rodrigo C. D., Paiva, M. T. D., \& Faisal, H. (2015). Spatiotemporal interpolation of discharge across a river network by using synthetic SWOT satellite data. Water Resources Research, 51(1), 430-449. http://dx.doi.org/10.1002/2014WR015618

Sanchis-Palacio, Joan, R., \& Amparo, M. (2011). Strategic diagnosis of Spanish farming cooperative credit sections: A SWOT analysis. Annals of Public and Cooperative Economics, 82(2), 167-186. http://dx.doi.org/10.1111/j.1467-8292.2011.00435.x

Schroeder, A., Minocha, S., \& Schneider, C. (2010). The strengths, weaknesses, opportunities and threats of using social software in higher and further education teaching and learning. Journal of Computer Assisted Learning, 26(3), 159-174. http://dx.doi.org/10.1111/j.1365-2729.2010.00347.x

Throsby, D. (2001). Economics and Culture. Cambridge: Cambridge Unversity Press.

Uysal, M., \& Hagan, L. A. R. (1993). Motivation of pleasure travel and tourism. In Khan et al. (Eds.), Encyclopedia of Hospitality and Tourism. New York: VNR.

Uysal, M., Gahan, L., \& Martin, B. (1994). An Examination of Event Motivations: A Case Study. Festival Management \& Event Tourism, 1(1), 5-10. Retrieved from http://www.ingentaconnect.com/content/cog/fmet/1993/00000001/00000001/art00002

Weiler, B., \& Hall, C. M. (1992). Introduction: What's Special About Special Interest Tourism? In B. Weiler, \& C. M. Hall (Eds), Special Interest Tourism (pp. 1-14). London: Belhaven Press.

Weihrich, H. (1982). The TOWS matrix tool for situational analysis. Long Range Planning, 15(2), 54-66. http://dx.doi.org/10.1016/0024-6301(82)90120-0

Weihrich, H. (1993). Daimler-Benz's Move towards the Next Century with the TOWS matrix. European Business Review, 93(1), 4-11. http://dx.doi.org/10.1108/EUM0000000001906

WTTC. (2014). World Economic Impact Report. Retrieved from http://www.wttc.org/research/economic-impact-research/regional-reports/world/

Willim, F. T. (1997). Global Tourism: The next decade. London: Butterworth Heinemann.

Xie, P. F. (2004). Visitors' Perceptions of Authenticity at a rural Heritage Festival: A Case Study. Event Management, 8(3), 151-160. http://dx.doi.org/10.3727/1525995031436908

Zeppei, H., \& Hall, C. M. (1992). Art and heritage tourism. In B. Weiler, \& C. M. Hall (Eds), Special Interest Tourism (pp. 47-68). London Belhaven. 


\section{Copyrights}

Copyright for this article is retained by the author(s), with first publication rights granted to the journal.

This is an open-access article distributed under the terms and conditions of the Creative Commons Attribution license (http://creativecommons.org/licenses/by/3.0/). 